\title{
RISCO HIDROCLIMÁTICO E IMPACTO DAS PRECIPITAÇÕES EM PLANÍCIES URBANAS DE BELÉM-PA
}

\section{HYDROCLIMATIC RISK AND IMPACT OF PRECIPITATIONS ON URBAN PLAINS OF BELÉM-PA}

\author{
José Edilson Cardoso Rodrigues ${ }^{1}$ \\ Luziane Mesquita da $\mathrm{Luz}^{2}$
}

\begin{abstract}
Resumo
Belém é considerada um dos municípios que apresentam um dos maiores índices pluviométricos do Estado do Pará. A combinação de alto índice pluviométrico com adensamento urbano pode ocasionar inundações principalmente, nas áreas de planície, onde a dinâmica do escoamento superficial é lenta, contudo, é grande o número de famílias afetadas, as perdas materiais e problemas de saúde são grandes. O objetivo do trabalho foi levantar a dinâmica e a distribuição da precipitação, e analisar a variabilidade hidrodinâmica nas bacias do Tucunduba, Estrada Nova, Una e Mata Fome. O trabalho está pautado no levantamento da precipitação a partir de dados temporais da série histórica do INMET e DECEA e espaciais adquiridos pela CEMADEN para a elaboração de cartas de precipitação utilizando o método de interpolação. Também foram elaborados mapas temáticos hipsométricos, geomorfológicos e drenagem. Foram gerados mapas de distribuição temporal da precipitação entre os anos de 2003 a 2016, mostrado as áreas de maior ocorrência e também a representação espacial da precipitação para uma data específica do ano de 2018, observou-se assim, as bacias com os maiores índices pluviométricos, e os transtornos na população em uma análise espacial. Os aspectos que condicionam a ocorrência de inundações estão diretamente relacionados a fatores naturais como relevo, tamanho e forma da bacia, gradiente hidráulico do rio, dinâmica de escoamento pluvial, falta de arborização e alto índice pluviométrico. Já os fatores antrópicos estão relacionados à impermeabilização dos terrenos, obras e intervenções estruturais diversas ao longo dos cursos d'água, erosão e assoreamento.
\end{abstract} Palavras-chave: Precipitação, urbanização, bacias urbanas, variabilidade.

\begin{abstract}
Belém is considered one of the cities that has one the highest rainfall in the state of Pará. The combination of high rainfall with an increase in urban may lead to flooding, especially in the plains areas, where the dynamics of the surface runoff is very slow, however is large the number of families affected and health conditions that are major. The objective of this study was to survey the dynamics and distribution of rainfall and variability of hydrodynamics within the river basins of Tucunduba, Estrada Nova, Una e Mata Fome. The study is based on a survey of the fallout from the time series of INMET, DECEA, and data taken by the CEMADEN for the mapping of rainfall using a method of interpolation. Also, set up thematic hypsometric maps, geomorphological and drainage. It was Generated time distribution maps over time of rainfall, between the years of 2003 to 2016, which is shown in the areas of higher incidence and also of the spatial representation of the rainfall for a particular date in the year 2018 at the latest, it was noted, and the bowls with the highest rainfall, and the population disorders in a spatial analysis. The aspects influencing the occurrence of floods are closely related to the natural factors such as topography, the size and shape of the watershed, the gradient of the hydraulic of the river, the dynamics of the drainage system, the lack of trees and heavy rainfall. Anthropic factors, on the other hand, are related to the waterproofing of land, works and various structures interventions along the water courses, erosion and silting.
\end{abstract}

Key Words: Rainfall, urbanization, urban basins, variability

\footnotetext{
1 Professor Doutor da Faculdade de Geografia e Cartografia da Universidade Federal do Pará. E-mail: jecrodrigues@ufpa.br

2 Professora Doutora da Faculdade de Geografia e Cartografia da Universidade Federal do Pará. E-mail: luzianeluz@ufpa.br
} 


\section{Risco hidroclimático e impacto das precipitações em planícies urbanas de Belém-Pa}

\section{INTRODUÇÃO}

A cidade de Belém apresenta um dos maiores índices pluviométricos do Estado do Pará, considerada o município das águas, tanto por ser contornado pela baía do Guajará e o rio Guamá, pelos elevados índices pluviométricos que variam de 2.600 a $3.300 \mathrm{~mm} /$ ano e pela alta umidade relativa do ar que pode chegar a $95 \%$ (NIMER, 1977).

Essas características de elevadas precipitações fazem com que o município de Belém apresente uma classificação climática conhecida como Clima equatorial quente superúmido sem seca, ou definida por Köppen como Clima quente úmido sempre úmido (Af) este mesmo tipo climático é observado também na porção do extremo oeste do Estado do Amazonas. Caracterizado por elevadas temperaturas, umidade e precipitação o ano todo. Esta característica subclimatica é definida pela elevada evapotranspiração (evaporação dos grandes rios e transpiração da floresta amazônica), e pela baixa latitude (próximo à linha do equador $0^{\circ}$ ). A precipitação pluviométrica, a temperatura do ar entre outros elementos do clima é largamente estudada em função da grande rede de estações meteorológicas e hidrológicas instaladas na região amazônica desde meados do séc. XX. O registro desses elementos e análises do comportamento desses parâmetros permite levantar questões como as alterações climáticas e seus impactos provocados por causas naturais ou antrópicas (MARENGO e NOBRE, 2009).

A variação espacial e a flutuação temporal são características marcantes do tempo e do clima. A flutuação temporal do clima é uma característica que deve ser abordada com maiores detalhes, pois o seu estudo nas mais diferentes escalas cronológicas permite compreender como as mudanças climáticas ocorreram em períodos diferentes.

Entretanto, deve-se lembrar de que no referido trabalho levará em consideração a escala de tempo de 30 anos, considerado como normal climática, para se obter resultados de variabilidade climática. A normal climática é um valor padrão reconhecido de um elemento meteorológico, considerando a média de sua ocorrência em um determinado local, por um número determinado de anos. "Normal" significa a distribuição dos dados dentro de uma faixa de incidência habitual. Durante esse tempo incluem-se considerações dos desvios em relação às médias, isto é, a variabilidade, condições extremas e as probabilidades de frequência de ocorrência de determinadas condições de tempo (AYOADE, 2003).

Os fenômenos climáticos e meteorológicos extremos acontecem regularmente e fazem parte da variabilidade natural do planeta, em busca do equilíbrio, já que algumas regiões recebem maior aquecimento solar do que outras, como é o caso da zona climática equatorial.

O conceito de Variabilidade Climática é entendido como uma propriedade intrínseca do sistema climático terrestre, responsável por oscilações naturais nos padrões climáticos, observados em nível local, regional e global. Muito embora alguns modelos apontem para cenários de maior variabilidade do clima (eventos extremos, menos previsibilidade, maior índice pluviométrico ou períodos de seca com maior tempo de estiagem) (CONFALONIER, 2003). Para Angelocci e Sentelhas (2007) a variabilidade climática é entendida como uma variação das condições climáticas em torno da média climatológica, diferenciando de 


\section{Risco hidroclimático e impacto das precipitações em planícies urbanas de Belém-Pa}

anomalia, que é uma flutuação extrema de um elemento em uma série climatológica, com desvios acentuados do padrão observado de variabilidade.

A Variabilidade Climática refere-se, também, ao desvio de estatística climática durante um dado período de tempo (por exemplo, um mês específico, uma estação de ano) em longo prazo, em relação ao calendário do clima correspondente ao mesmo período. Deste modo, descreve como o clima, durante um período de tempo comparativamente curto, varia de médias climáticas em longo prazo, com consequências diretas na gestão de recursos hídricos. Por exemplo, um resultado direto pode ser a mudança na disponibilidade de recursos hídricos superficiais e subterrâneos.

O que também é igualmente importante é a variabilidade da precipitação, onde as regiões que sofrem de alta variabilidade da precipitação, também sofrem de altos níveis de incerteza, o que se traduz em um alto nível de risco a partir das cheias e secas.

Quando a água precipita em volume acima do esperado, principalmente em ambiente urbano, uma das consequências são as enchentes e inundações, causando grandes riscos à população principalmente de famílias assentadas precariamente.

A mudança do padrão do regime e volume de chuva pode ser causada pela mudança no padrão da urbanização, assim como a intensa impermeabilização do solo e retificações e assoreamento de canais urbanos, podendo comprometer nos processos de enchentes e alagamentos em áreas urbanas (ADLER e TANNER, 2015).

A combinação de alto índice pluviométrico com adensamento urbano pode ocasionar fenômenos como; extravasamento das águas do canal de drenagem urbana para as áreas marginais, definidas como planície de inundação ou várzea, podendo atingir cotas acima do nível máximo da calha principal do canal urbano. Essas áreas passíveis de serem atingidas por processos de enchentes e inundações, geralmente são bastante populosas e as pessoas que habitam essas áreas estão sujeitas a danos à integridade física, perdas materiais e patrimoniais. Normalmente, essas áreas correspondem a núcleos habitacionais de baixa renda.

Em cidades com relevo bastante acidentado, os efeitos adversos de enchentes e inundações causam mortes, destruição de moradias, perdas econômicas diversas e grandes gastos públicos. Os danos são mais acentuados devido à alta energia de impacto destrutivo que ocorre geralmente em anfiteatros de drenagem de relevo serrano, como é o caso de cidades como Marabá, Parauapebas, localizadas mais ao sul do estado do Pará.

Em caso de cidades com relevo plano, como é o exemplo da cidade de Belém-PA, as inundações de extensas áreas de baixadas estão associadas, principalmente, à planície de inundação dos rios e canais, onde a dinâmica do escoamento superficial é lenta, é grande o número de moradias afetadas, geralmente não há registro de perda de vidas humanas, entretanto, perdas materiais e problemas como: surtos de leptospirose, diarreia, dengue, entre outras doenças associadas à água, são bastante frequentes.

A pesquisa justifica-se, pela falta de estudos mais direcionados que relacionem os problemas de alagamentos, inundações e transbordamentos em planícies urbanas de Belém com os altos índices pluviométricos, e segundo, os aspectos que condicionam a ocorrência de enchentes e inundações estão 


\section{Risco hidroclimático e impacto das precipitações em planícies urbanas de Belém-Pa}

diretamente relacionados a fatores naturais como, relevo, tamanho e forma da bacia, gradiente hidráulica do rio, dinâmica de escoamento pluvial, alto índice pluviométrico e fatores antrópicos como à impermeabilização dos terrenos; obras e intervenções estruturais diversas ao longo dos cursos d'água; erosão e assoreamento (RODRIGUES et al, 2017).

Portanto, o monitoramento e o acompanhamento de fatores climáticos, como volume pluviométrico e os processos de uso e ocupação das áreas de bacias urbanas da cidade de Belém, são importantes para o controle de enchentes e alagamentos, assim como combater e prevenir a população, que residem em áreas crônicas de alagamento, de doenças vinculadas à água parada e que são mais concentradas no período chuvoso.

O principal objetivo do trabalho foi levantar a dinâmica e distribuição da precipitação nas planícies dos Canais da Tamandaré, Reduto-Umarizal, Tucunduba e Estrada Nova, assim como analisar a variabilidade hidroclimática, considerando que a magnitude da média pluviométrica pode ser capaz de causar inundações, alagamentos e transbordamento de canais, proporcionando transtornos à população.

\section{MATERIAIS E MÉTODOS}

O trabalho foi pautado no levantamento de dados temporais e espaciais de precipitação. Os dados temporais foram levantados a partir da série histórica de pluviosidade das estações Belém, do tipo Convencionais e Automáticas disponíveis no site do Instituto Nacional de Meteorologia (INMET) e da Estação Automática do Departamento de Controle do Espaço Aéreo - DECEA.

Os dados espaciais foram levantados a partir de pluviômetros digitais que foram colocados no perímetro das bacias em estudo pelo Centro Nacional de Monitoramento e Alerta de Desastres Naturais (CEMADEN) disponível no site www.cemaden.gov.br.

De posse dos dados de precipitação, foram elaboradas cartas de precipitação em programa SIG, ArcGis, utilizando o método de interpolação de dados tendo como referência dados de chuva das estações e dos pluviômetros digitais.

Os mapas de declividade e geomorfológico de cada bacia foram elaborados com base em curvas de nível de $2 \mathrm{~m}$ disponibilizadas pela CODEM (1998). A rede de drenagem de cada bacia foi vetorizada em imagens de IKONOS (2006). Por fim foi realizado trabalho de campo para observações, descrições e registros das enchentes, alagamentos e seus respectivos danos às populações atingidas. A produção cartográfica foi realizada no Laboratório de Análises de Informação Geográfica - LAIG e a parte de análise e tratamento dos dados foi feita no Laboratório de Geografia Física - LAGEOF /FGC/UFPA. 
Risco hidroclimático e impacto das precipitações em planícies urbanas de Belém-Pa

\section{RESULTADO E DISCUSSÕES}

\section{Impactos Antropogênicos nas Planícies Urbanas de Belém}

A combinação do alto índice pluviométrico no contexto de consolidação urbana do sítio antropogênico de Belém e a falta de concretização das metas estabelecidas no planejamento urbano, tem repercutido em problemas urbanos seculares com o aumento da frequência e magnitude das inundações dos canais urbanos, devido a falta de dimensionamento das bacias urbanas para receber o volume das chuvas. Em Belém, as áreas críticas atingidas por processos de enchentes e inundações, correspondem às planícies urbanas que constituem zonas populosas. Essas áreas estão sujeitas a danos à integridade física, perdas materiais e patrimoniais permanentes. As características do relevo da cidade de Belém-PA (Figura 01), que exibe áreas planas com inundações de extensas áreas de baixadas localizadas principalmente junto às planícies dos rios e canais, onde a dinâmica do escoamento superficial é lenta, está ocasionando danos a um grande número de moradias.

\section{Figura 01: Mapa Geomorfológico de Belém}

\section{MAPA GEOMORFOLÓGICO DA PRIMEIRA LÉGUA PATRIMONIAL DE BELÉM.}
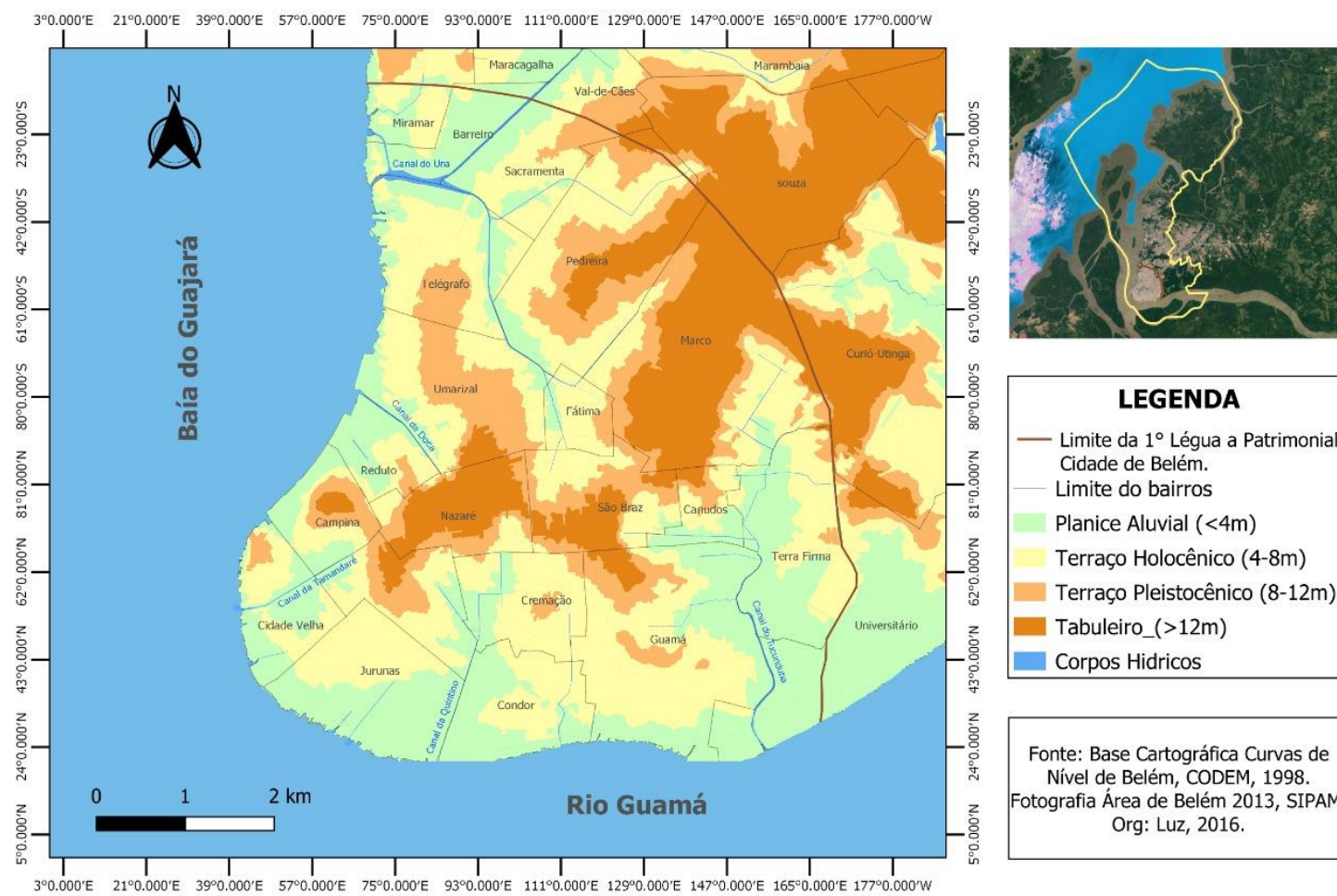

— Limite da $1^{\circ}$ Légua a Patrimonial Cidade de Belém. Limite do bairros

Planice Aluvial $(<4 \mathrm{~m})$

Terraço Holocênico (4-8m)

Terraço Pleistocênico (8-12m)

Tabuleiro_(>12m)

Corpos Hidricos

Fonte: Base Cartográfica Curvas de Nível de Belém, CODEM, 1998. Fotografia Área de Belém 2013, SIPAM. Org: Luz, 2016.

Fonte: LUZ, 2016

As planícies urbanas correspondem às unidades de relevo mais afetadas no cenário atual. As planícies urbanas históricas apesar de apresentarem-se consolidadas do ponto de vista da urbanização, apresentam problemas geotécnicos decorrentes do tipo de depósito antropogênico utilizado no aterramento dessas áreas que tornaram-se um grande vetor da verticalização de alto gabarito nas últimas décadas. 


\section{Risco hidroclimático e impacto das precipitações em planícies urbanas de Belém-Pa}

A planície urbana da Tamandaré foi o locus das primeiras intervenções em área de influência de bacias hidrográficas na cidade de Belém. Durante o século XIX, passou por importantes obras de implantação de tubulações para o escoamento das águas, afundamento de cursos d'água e aterramento da extensa planície de inundação do Igarapé do Piri. Durante a década de 60 do século XX, o canal sofreu obras estruturais com o processo de retificação do canal atual e implantação de sistemas de comportas automáticas na foz. Depois de séculos de intervenções antropogênicas e após um evento chuvoso no período de marés de equinócio, os canais rapidamente transbordam inundando toda a área adjacente. Na análise dos eventos chuvosos fevereiro de 2014, foi registrado que o Canal da Tamandaré sofreu transbordamento inundando toda a área adjacente, as enchentes são mais frequentes em períodos coincidentes com as marés de equinócio e volume de chuva acima do esperado (Figura 02).

Figura 02: Registro de Transbordamento do Canal da Tamandaré 03 de Fevereiro de 2014 após forte chuva.

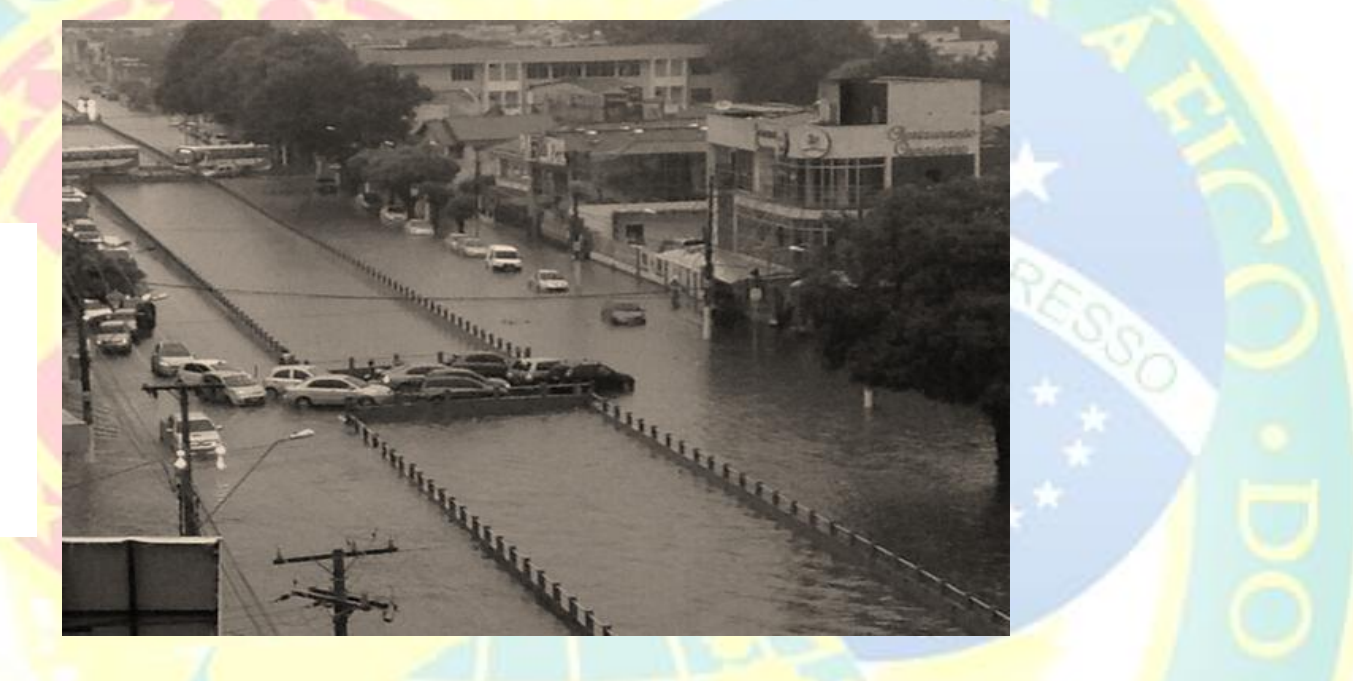

Fonte: http://www.amazonianarede.com.br/chuva-deixa-vias-alagadas-em-belem.

A Planície urbana do Reduto-Umarizal, passou por diferentes fases de obras e intervenções morfológicas desde o processo de transformação do igarapé em sistemas de docas no litoral, para o ancoradouro de embarcações até a transformação completa em um canal urbano. O uso de estacas de madeira no igarapé do Reduto começou em meados do século XIX, e depois foram implantadas estruturas mais duradouras, para o escoamento das águas foi realizado o enterramento de tubulações e obstrução da foz para a edificação de diques de contenção de enchentes durante a construção do Porto de Belém, a obstrução da foz original levou a construção de sistemas de comportas automáticas e desvio de águas da bacia do reduto para o canal da Doca de Souza Franco, formando uma única bacia, hoje conhecida como bacia do Armas-Reduto que sofreu importantes transformações hidrológicas.

A planície do Reduto-Umarizal é um vetor da verticalização de altos gabaritos que não respeita a legislação do uso do solo estabelecida pelo plano diretor e demais instrumentos de planejamento urbano. Na área observamos o estímulo da verticalização com IA (Índice de Aproveitamento), é o coeficiente de aproveitamento máximo do terreno que é o resultado entre o quociente total da área construída da edificação e a área do terreno (Lei complementar de controle urbanístico n.2/99 de 19 de julho de 1999) com no máximo 
de 4.0 para moradias multifamiliares, através do pagamento de outorga onerosa pelas incorporadoras que levou a concretização de grandes edificações verticais que propõe vista panorâmica para a Baía do Guajará. A planície é sustentada do ponto de vista geotécnico por materiais argilosos de consistência muito mole e no topo depósitos tecnogênicos arenosos remobilizados de origem fluvial, constituem em zonas de alto risco geomorfológico devido a ocorrências de subsidências de moradias localizadas no entorno de grandes torres verticais. As torres verticais também sofrem problemas de recalque imediato, devido ao suporte arenoso e as argilas da base mostram um comportamento plástico a longo prazo.

A área da planície é afetada por inundações excepcionais, sobretudo do período do equinócio, quando ocorrem as maiores marés do ano. A frequência de inundação do canal vem aumentando, mesmo em situação de comportas fechadas, os canais do sistema Armas-Reduto não suportam a quantidade de água de origem pluvial e a entrada das marés. No contexto de variabilidade da precipitação no mês fevereiro de 2014, registramos o transbordamento dos canais devido ao elevado índice pluviométrico, inundando toda a área adjacente (Figura 03).

Figura 03: Registro de Transbordamento do Canal da Doca de Souza Franco após forte chuva ocorrida em 03 de fevereiro de 2014.

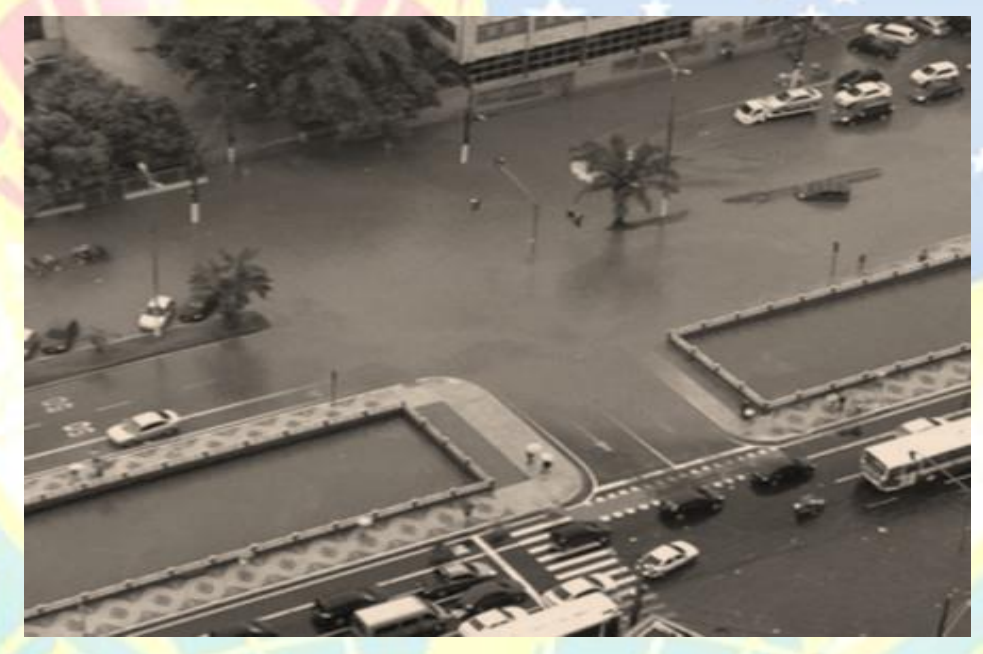

Fonte: http://www.amazonianarede.com.br/chuva-deixa-vias-alagadas-em-belem.

As planícies urbanas precárias são classificadas como Zonas Especiais de Interesse Social de acordo com o plano diretor de Belém. O cenário atual é marcado pela continuidade de problemas seculares, devido a negligência do poder público e a falta de investimento na área que se constitui em zonas de risco geomorfológico e geotécnico. O aumento da precipitação tem afetado a planície do Tucunduba diretamente. Desde a década de 90, a planície passa por obras e intervenções pontuais, seus canais passaram por diferentes fases de estreitamento através de implantação de estacas de madeira rudimentar para contenção das margens do canal e a posteriori por implantação de estruturas mais duradouras como uso de concreto. Do ponto de vista topográfico a bacia do Tucunduba apresenta extensas áreas de planícies na cota abaixo de $4 \mathrm{~m}$ de altitude, a forma da bacia extremamente alongada e a densa ramificação de canais urbanos alterados por processos de 


\section{Risco hidroclimático e impacto das precipitações em planícies urbanas de Belém-Pa}

aterramento, estreitamento de canais, estrangulamentos por implantação de vias e desvios são os principais fatores que contribuíram para a formação de áreas crônica de inundação.

A planície do Tucunduba é o principal locus das ocupações precárias na área central de Belém, correspondem a zonas de grande adensamento horizontal que historicamente abriga a população de baixa renda e não possui regularização dos lotes urbanos, porém a Lei 8739 de 19 de maio de 2010 institui o programa municipal de regularização fundiária. A Companhia de Desenvolvimento Metropolitano tem direcionado especial atenção e prioridade às famílias que se encontram em situação de vulnerabilidade social. As condições geotécnicas da planície sustentada por materiais argilosos de consistência muito mole e no topo depósitos tecnogênicos gárbicos como lixo e caroço de açaí material amplamente utilizado para o nivelamento da planície alagada, constituem em zonas de alto risco geomorfológico devido a ocorrências de subsidências de moradias com perdas materiais para a população.

Na atualidade a planície do Tucunduba passa por obras pontuais, executadas pela Secretaria de Estado de Integração do Desenvolvimento Urbano Regional, que envolvem a conclusão do processo de macrodrenagem da bacia do Tucunduba. As obras têm a finalidade de diminuir os problemas de inundação crônicos na bacia. O projeto de intervenção em andamento foi iniciado em 2012 e objetiva definir as obras necessárias para o alargamento e a retificação do leito do Igarapé Tucunduba, através da utilização racional do canal para melhorar as condições de navegabilidade do Tucunduba e promover a integração viária entre as áreas adjacentes ao canal, facilitando o acesso e a locomoção dos moradores. A retificação do canal do Tucunduba irá possibilitar a eliminação dos problemas nos demais canais da bacia. Com base nas simulações efetuadas, foi possível concluir que a escavação de todo o canal do Tucunduba, incluindo o trecho à jusante da rua São Domingos, seria uma opção para atender apenas a situação de maré baixa o que resolveria apenas parcialmente o problema atual e, dessa forma, não seria a melhor proposição técnica. Na situação de maré alta, a maré entrante usa uma grande parte da capacidade de armazenamento criada pelo alargamento do Tucunduba, indicando que o alargamento do canal, por si só, não é suficiente para conter os alagamentos (PMB, 2012).

A bacia e seus respectivos canais urbanos apresentam problemas crônicos de transbordamento nos períodos mais chuvosos e também em períodos de chuvas rápidas e abundantes que levam os canais a atingirem rapidamente o pico da cheia. $\mathrm{O}$ aumento do volume de chuvas na porção sudeste da área central vem afetando, sobretudo, substancialmente a Bacia do Tucunduba que corresponde a segunda maior bacia urbana da cidade, que ainda não passou por um amplo processo de macrodrenagem estrutural. Em março de 2016, o volume de chuva precipitado ultrapassou a capacidade de vazão do canal. Os transbordamentos crônicos são comuns nos canais urbanos: Cipriano Santos, José Leal Martins, Gentil, Mundurucus entre outros (Figura 04). 


\section{Risco hidroclimático e impacto das precipitações em planícies urbanas de Belém-Pa}

Figura 04: Transbordamento dos Canais Cipriano Santos e Tucunduba, na sua confluência.

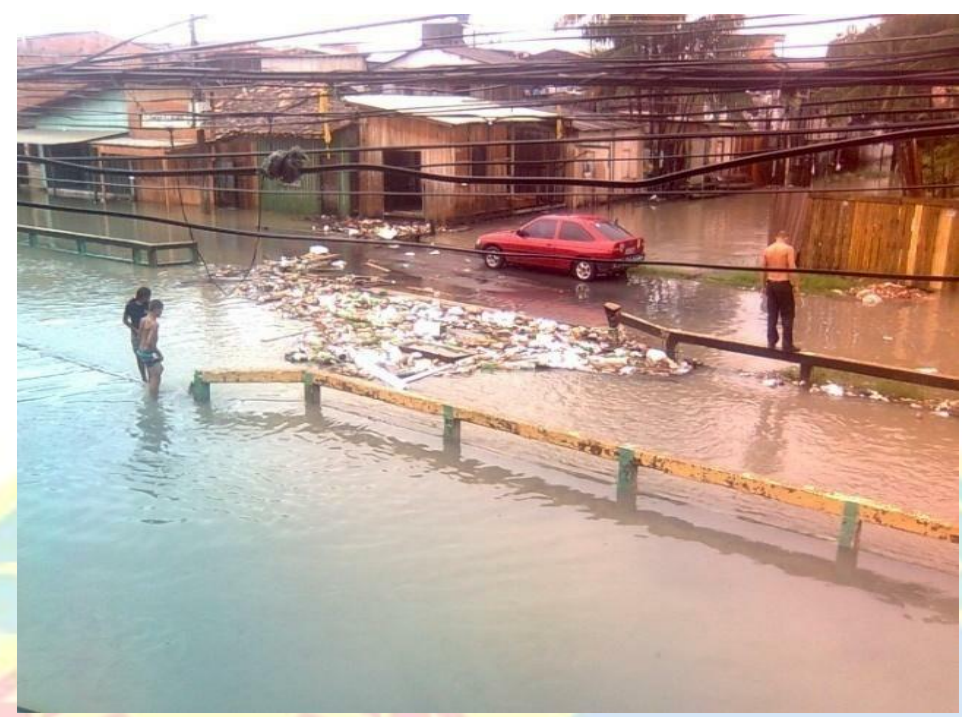

Fonte: SILVA (2016).

A Planície Urbana da Estrada Nova encontra-se em uma situação atual de execução do projeto de macrodrenagem da Bacia da Estrada. Observamos mudanças morfológicas importantes na rede de canais tais como afundamento e fechamento de canais para a construção de ruas e avenidas como ocorreu nos canais da Caripunas (Figura 05) e Timbiras, aterramento de extensas áreas do canal da Bernardo Sayão que levaram ao surgimento de inundações a montante dos canais onde estão sendo executadas as obras de controle contra as inundações. O aumento da precipitação nas últimas décadas, foi considerado como um input que vem causando impactos nas bacias urbanas como vem sendo registrado pela população que evidencia o aumento do transbordamento dos canais e inundação das áreas adjacentes. As obras de contenção das enchentes na bacia da Estrada Nova estão ocorrendo de uma forma sistemática desde a implementação do Projeto de Reabilitação Urbano Ambiental da Bacia da Estrada Nova que tem a finalidade de fechamento, desvios e construção de bacias de contenção em pontos críticos da bacia. No entanto, observamos que as obras estão concentradas a jusante dos canais e o alto curso sofre com as inundações crônicas em épocas de chuvas concentradas.

Figura 05: Canal da Caripunas durante as obras de implantação de sistemas de galerias.

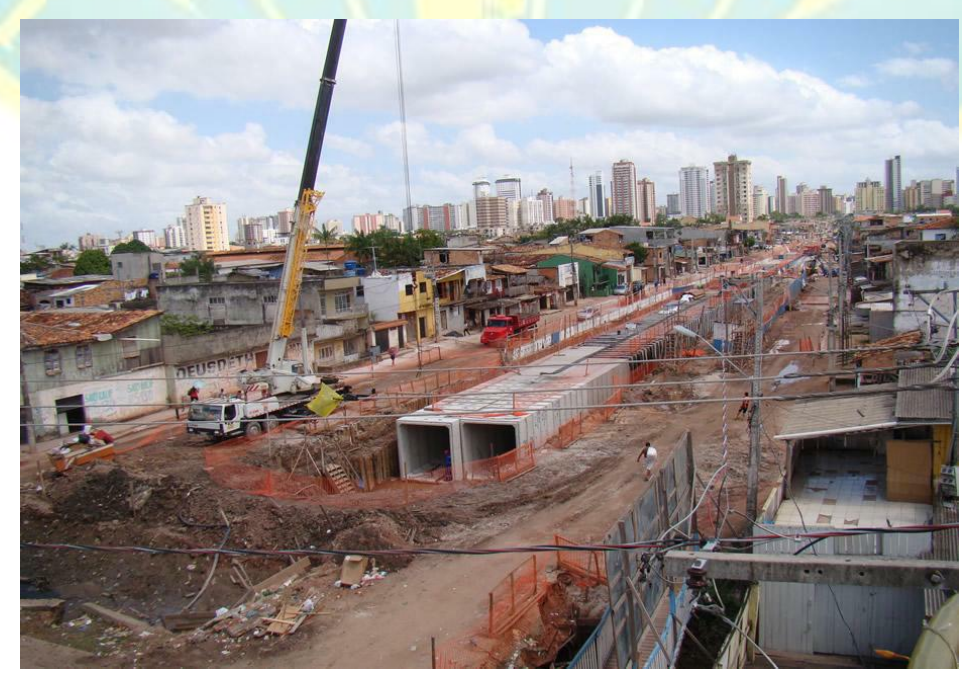

Fonte: PMB (2006). 


\section{Risco hidroclimático e impacto das precipitações em planícies urbanas de Belém-Pa}

$\mathrm{Na}$ atualidade a bacia da Estrada Nova é o principal alvo de intervenções estruturais, desde 2006 estando inserido no contexto do Programa de Reabilitação Urbana e Ambiental da Bacia Hidrográfica da Estrada Nova - PROMABEN. A obra está executando a macro e micro drenagem de canais, que contempla a construção de sistemas de drenagem de águas pluviais, a proteção de cabeceiras, proteção de margens, construção e adequação de canais, criação de espaços públicos de lazer e preservação ambiental, e implantação de galerias e coletores pluviais (PMB, 2006).

O Diagnóstico Sanitário e Ambiental da Bacia Hidrográfica da Estrada Nova, apontou os seguintes problemas na área de influência da bacia: alta incidência de vias ainda não implantadas ou sem pavimentação; a incidência de vias não atendidas por redes de abastecimento de água potável, falta de redes coletoras de esgotos sanitários e lançamento direto de esgotos "in natura" na rede de drenagem pluvial e nos canais. A inexistência e/ou insuficiência de redes coletoras e interceptores de esgotos, faz com que os efluentes sanitários sejam despejados nos cursos d'água ou na rede de drenagem, contribuindo para a poluição hídrica dos corpos d'água. A incidência de vias sem coleta de lixo e varrição. O fato de existirem vias sem pavimento dificulta sobremaneira o atendimento pelos serviços de limpeza urbana. Além disso, há inúmeros pontos detectados com acúmulo de resíduos sólidos urbanos; a alta incidência de transporte e acúmulo de sedimentos.

A despeito das faixas de preservação permanente dos canais de macrodrenagem, comprometendo as planícies de inundação dos cursos d'água, além de contribuir para a degradação ambiental. O que gera a ocorrência de inundações nos canais de macrodrenagem, principalmente nos trechos próximos às transposições viárias, onde a seção de escoamento dos bueiros não comporta o volume das cheias e representa um obstáculo ao fluxo natural das águas, tornando-se causa potencial para a elevação dos níveis das águas e consequentes inundações nas vizinhanças.

A situação de obras em andamento na planície tem afetado a vida da população local, devido à lentidão das obras que perduram por décadas. O aumento da precipitação no mês de fevereiro de 2016, que registrou precipitação acima dos $600 \mathrm{~mm}$, causou impactos no canal da 14 de março na planície tecnogênica da Estrada Nova, devido ao fechamento, desvios e afundamento de canais urbanos. No entanto, observamos que as obras estão concentradas a jusante dos canais e o alto curso sofre com as inundações crônicas em épocas de chuvas concentradas e abundantes (Figura 06). 
Figura 06: Transbordamento do canal da 14 de março, Bacia da Estrada Nova.

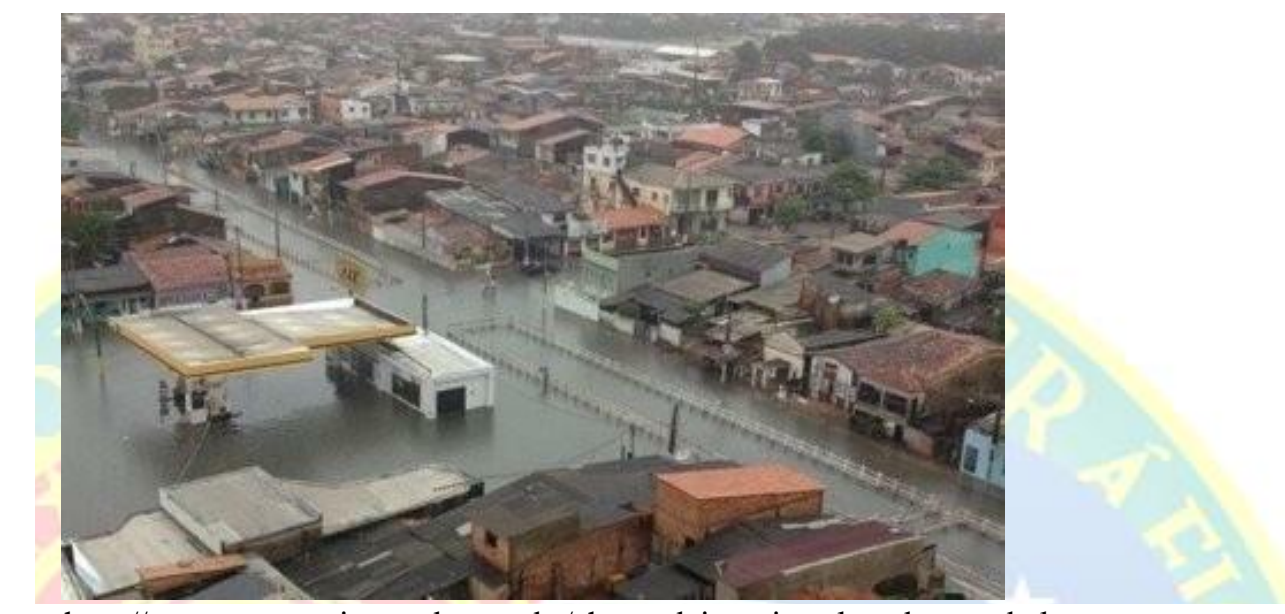

Fonte: http://www.amazonianarede.com.br/chuva-deixa-vias-alagadas-em-belem

A intervenção prevista na bacia tem a finalidade de implantação e interligação das redes coletoras de esgotos sanitários, o tratamento adequado dos efluentes sanitários coletados, a detecção e remoção de ligações clandestinas de esgoto à rede pluvial, bem como de descargas diretas nos canais de macrodrenagem, a implantação de dispositivos de drenagem como: redes coletoras e distribuidoras de águas pluviais, bocas-delobo, sarjetas, dissipadores de energia, bacia de acumulação temporária de águas pluviométricas, entre outros, dispositivos de detenção de sedimentos, desassoreamento e saneamento ambiental dos pontos críticos dos corpos hídricos, de forma a erradicar áreas de alagamento e contribuir para a melhoria sanitária e consequentemente, da saúde da população (PMB, 2006).

\section{PARÂMETROS PLUVIOMÉTRICOS OCORRIDOS NAS BACIAS URBANAS DE BELÉM}

Considerando a posição geografia de caráter equatorial, por estar relativamente próxima a região costeira e por ser margeado por dois grandes corpos hídricos o Rio Guamá e a Baía do Guajará, as precipitações pluviométricas constituem o elemento de maior vulnerabilidade dentro do escopo climatológico da cidade de Belém, onde os eventos pluviais extremos ou a estiagem em qualquer magnitude repercute sobremaneira na população urbana como um todo, podendo resultar em grandes prejuízos econômicos e de saúde.

Através da análise geográfica da chuva para as bacias do Una, Mata Fome, Estrada Nova e Tucunduba, no tempo e no espaço identificou-se situações pluviais habituais e eventos extremos de uma série histórica de dados pluviométricos.

A espacialização da pluviosidade permitiu uma melhor visualização da distribuição e da quantidade de chuva nas bacias. Para ilustrar e integrar as análises temporais e espaciais, construiu-se mapas de precipitação tempo-espacial dos regimes das chuvas médias. 
Risco hidroclimático e impacto das precipitações em planícies urbanas de Belém-Pa

\section{Análise Pluviométrica Temporal ocorrido nas Bacias anos de 2003 a 2016}

Para a elaboração dos mapas de precipitação adotou-se os anos de 2003 a 2016 para a análise temporal e o mês de maio de 2018 para análise espacial.

Primeiramente analisamos as médias dos anos de 2003 a 2008, as médias dos 2009 a 2013 e as médias dos anos de 2014 a 2016. A cartografia pluviométrica apresenta a distribuição temporal da pluviosidade média dos anos de 2003 a 2008 (Figura 07), pluviosidade média dos anos de 2009 a 2013 (Figura 08) e pluviosidade média dos anos de 2014 a 2016 (Figura 09).

Figura 07: Mapa da Precipitação acumulada trimestral na área continental de Belém (2003-2008)

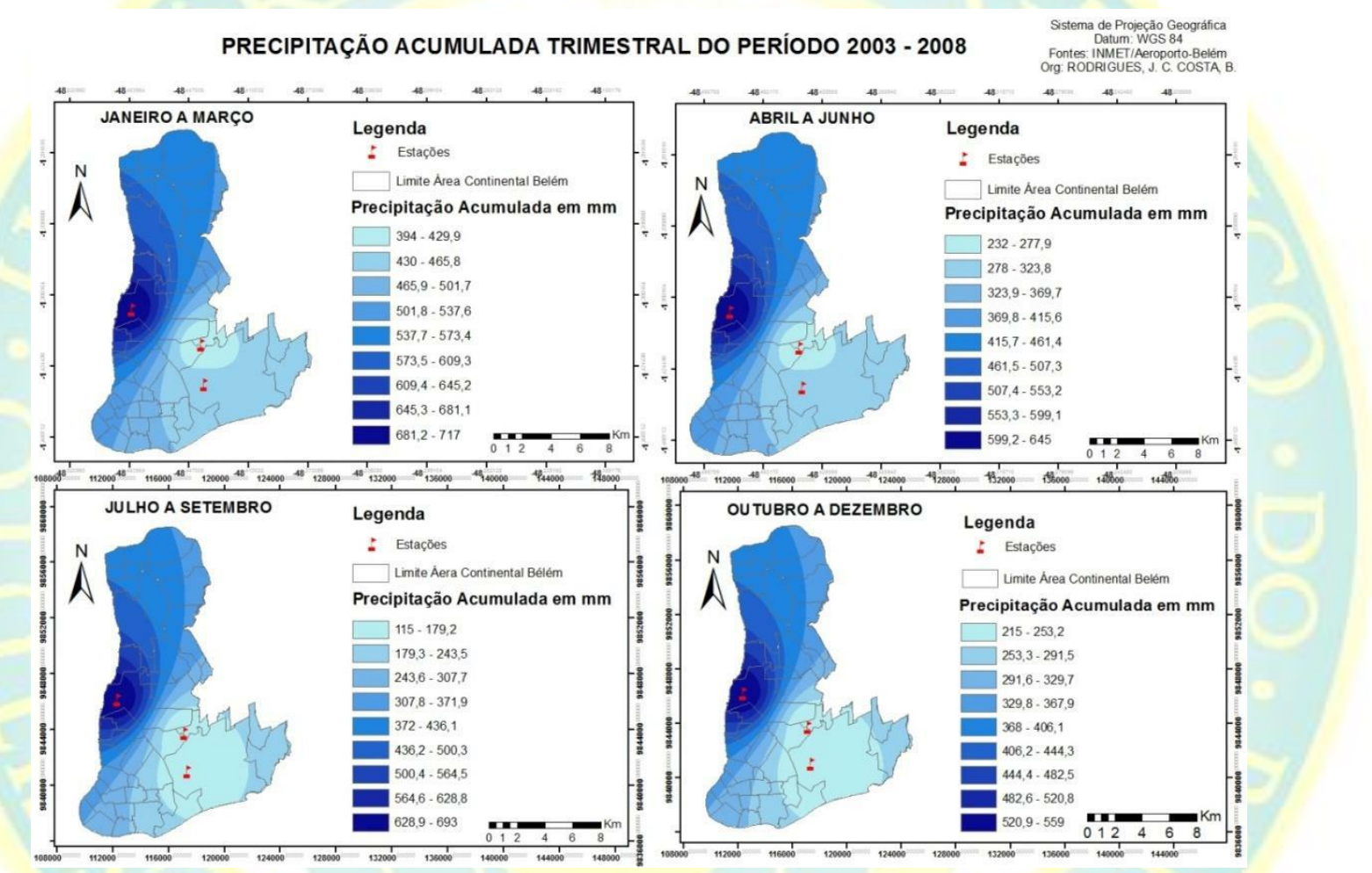


Figura 08: Mapa da Precipitação acumulada trimestral na área continental de Belém (2009-2013)

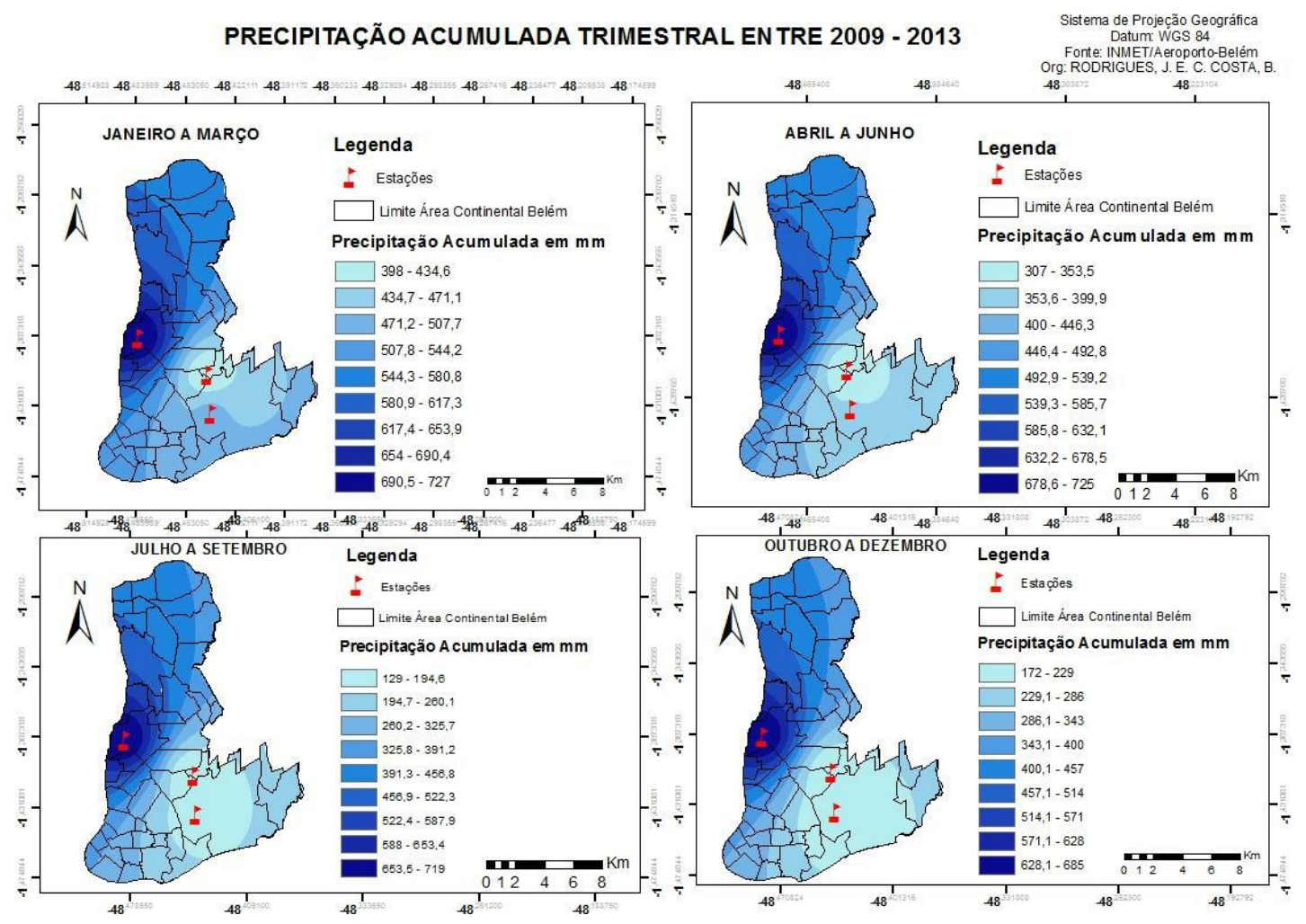

Figura 09: Mapa da Precipitação acumulada trimestral na área continental de Belém (2014-2016)

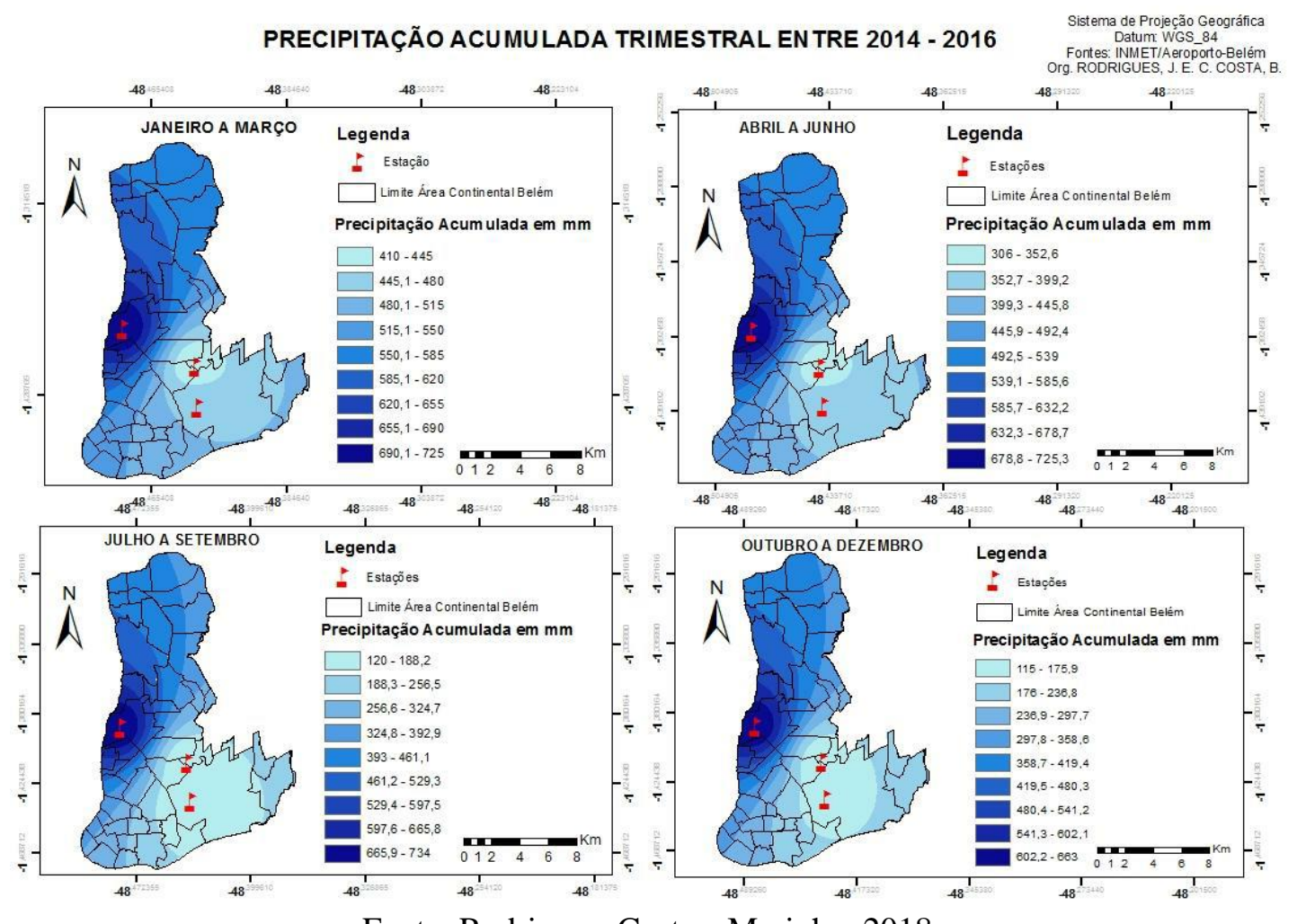

Fonte: Rodrigues, Costa e Marinho, 2018

Dentre os meses analisados os meses de julho a setembro dos anos de 2014 a 2016 foram os mais chuvosos apresentando um acumulado que variou entre 665,9 a $734 \mathrm{~mm}$, seguido pelos meses de janeiro e 


\section{Risco hidroclimático e impacto das precipitações em planícies urbanas de Belém-Pa}

março mais chuvoso dos anos de 2009 a 2013 que variou entre 690,5 a $727 \mathrm{~mm}$ e de 2003 a 2008 registrando entre 681,2 a $717 \mathrm{~mm}$.

Observou-se novamente que dentre as bacias analisadas, as Bacias do Una e Mata Fome, foram as que tiveram os maiores acúmulos durante os períodos mensais, ou seja, onde mais houve elevada precipitação, seguido pela bacia da Estrada Nova e pela Bacia do Tucunduba com totais mais reduzidas, confirmando assim a identificação de duas áreas com características pluviométricas relativamente contrastantes, com destaque para a região mais Norte-Oeste com maior nível precipitado e Leste-Sul com menor nível precipitado também quando se eleva em consideração a precipitação mensal.

\section{Impacto pluviométrico nas planícies urbanas de Belém}

Para a análise da distribuição espacial da chuva na área das planícies urbanas estudadas, optou-se por analisar o episódio do dia 07 de maio de 2018 que desencadeou diversos problemas entre eles inundações de canais e ruas, causando sérios danos à população. A análise espacial da dinâmica hidroclimática nas planícies urbanas só foi possível graças à instalação de várias estações hidroclimáticas em diversos pontos da cidade de Belém em especial nas áreas de bacias de nossos estudos feitos pela prefeitura em parceria com a Defesa Civil Municipal, que estabeleceram diversos pontos de coleta onde foram instalados os pluviômetros e denominadas de estações (Figura 10).

Figura 10: Rede Espacial de Estações de Registro de Precipitação na cidade de Belém-Pa.

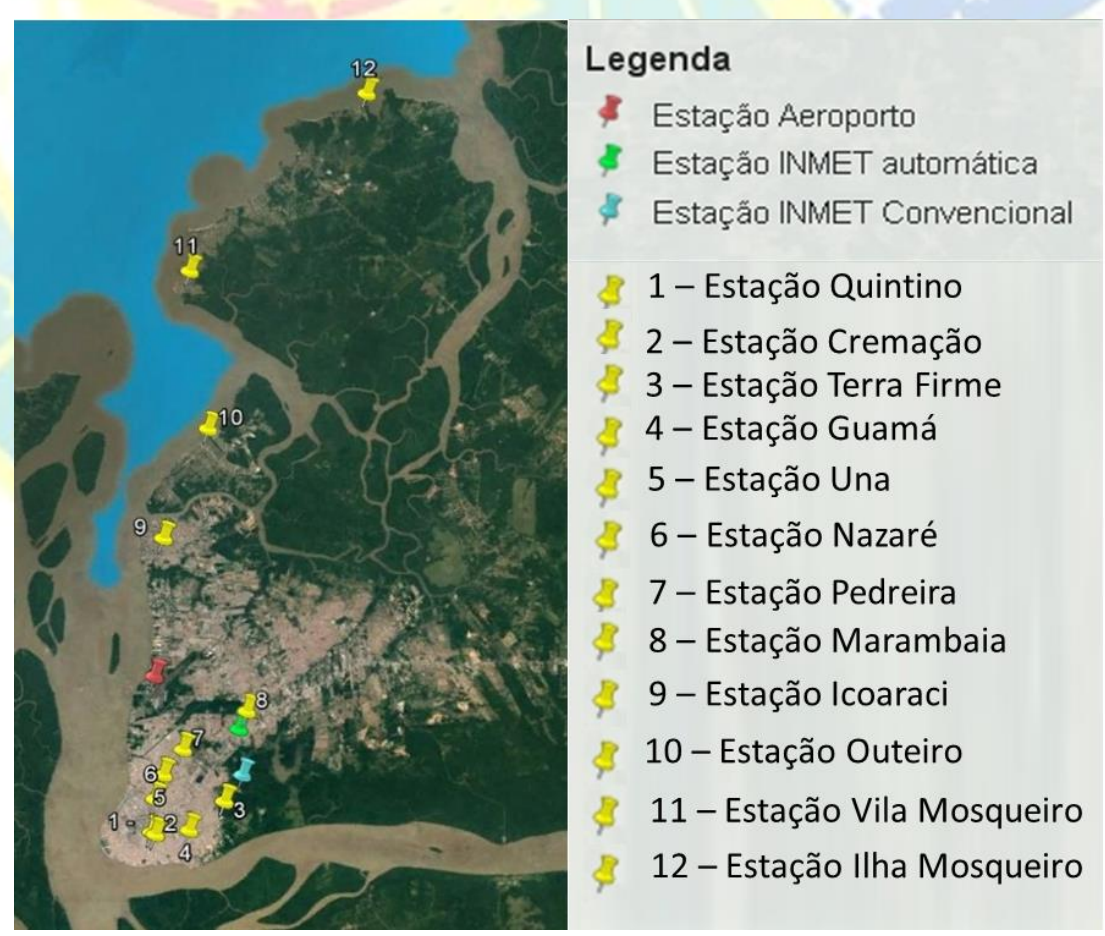

Fonte: Google, 2018. 


\section{Risco hidroclimático e impacto das precipitações em planícies urbanas de Belém-Pa}

De posse dos dados de precipitação gerada pelas estações foi possível representar a distribuição espacial precipitação ocorrida no dia 07 de maio de 2018 (Figura 11).

Figura 11: Mapa de precipitação espacial ocorrido no dia 07/05/2018

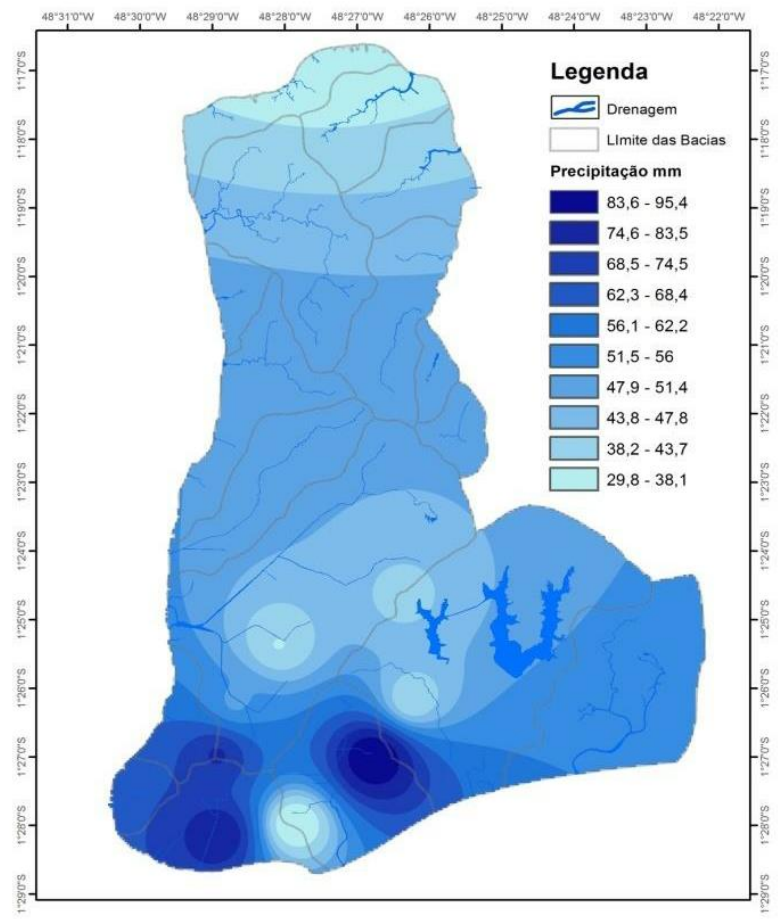

Fonte: Produção do Próprio autor, 2018

No dia anterior dia 06 de maio de 2018 havia ocorrido uma forte chuva que causou muitos transtornos a população e principalmente nas áreas de planícies das bacias nesse dia foi registrada mais de $60 \mathrm{~mm}$ na estação Terra Firme, instalada no perímetro da Bacia do Tucunduba, estação Nazaré instalada no perímetro da Bacia da Estrada Nova e na estação do Una instalada no perímetro da Bacia do Una, onde foi possível elaborar o mapa da precipitação.

Porém, no dia 07 de maio de 2018 a estação Terra Firme, registrou quase $100 \mathrm{~mm}$ de chuva, isso quer dizer que choveu mais de $100 \mathrm{~mm}$ por $\mathrm{m}^{2}$ no perímetro da bacia do Tucunduba. O segundo maior volume de precipitação, nesse dia foi, foi registrado na Estação Cremação pouco mais de $80 \mathrm{~mm}$, mostrando que na bacia da Estrada Nova choveu mais de $80 \mathrm{~mm}$ por $\mathrm{m}^{2}$ no perímetro da bacia.

$\mathrm{Na}$ bacia do Una o volume registrado ficou entre $50 \mathrm{~mm}$, ficando abaixo do que foi registrado nas bacias do Tucunduba e Estrada Nova (Gráfico 01). 
Gráfico 01: Registro da precipitação ocorrida entre os dias 01 a 08 /05 / 2018.

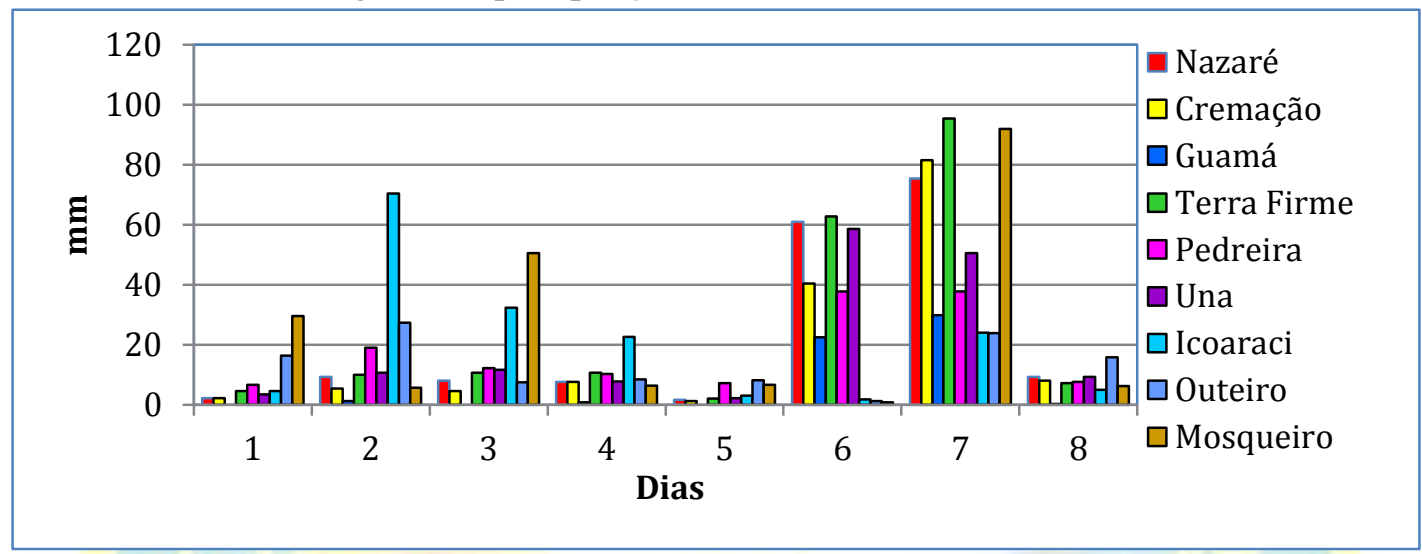

Fonte: Produção do Próprio autor, 2018

\section{O Impacto da chuva do episódio do dia 07/05/2018.}

Os primeiros sinais da calamidade apareceram no trânsito que ficou totalmente engarrafado dificultado a circulação dos veículos (Figura 12), transtorno no retorno da volta para casa, em decorrência de vários canais apresentarem transbordamento e vários locais que ficaram alagados, causado estresse e lentidão no trânsito assim como houve vários arrastões e assaltos as pessoas que retornavam a pé para suas residências como demonstrou a reportagem feita pelo diário do Pará (DOL, 08/05/2018)

Figura 12: Transito totalmente parado após chuva

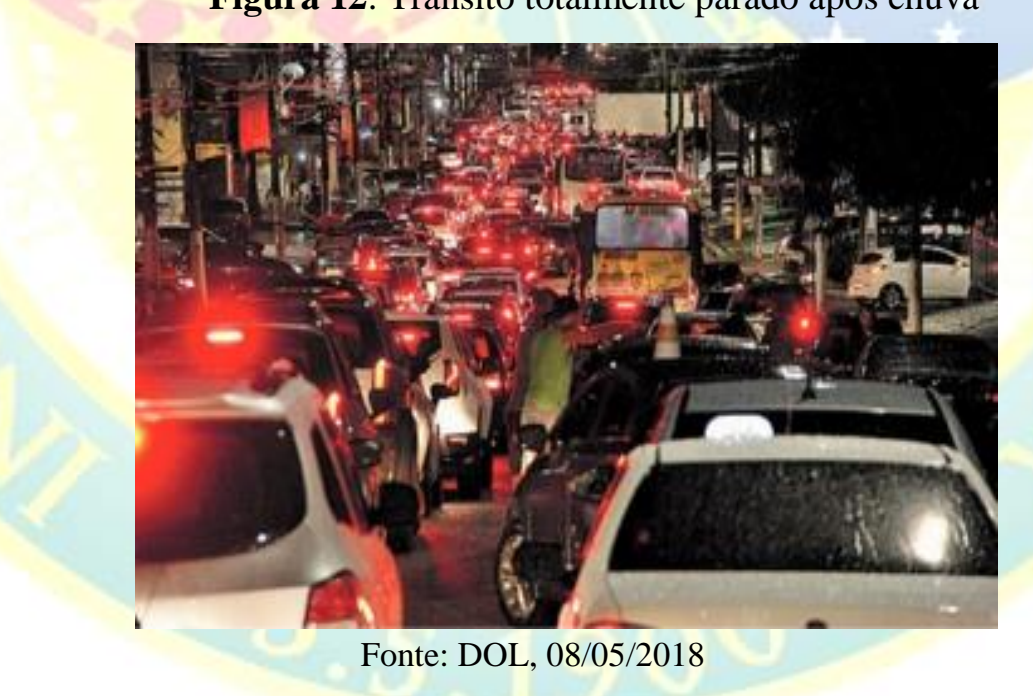

Diversos canais transbordaram com a combinação de alto índice pluviométrico com o adensamento urbano e o escoamento superficial das águas, principalmente nas áreas marginais, definidas como planícies de inundação (várzeas). Essas áreas passíveis de serem atingidas por processos de enchentes e inundações geralmente são bastante populosas e as pessoas que habitam essas áreas estão sujeitas a danos à integridade física, perdas materiais e patrimoniais (Rodrigues et al, 2017).

No episódio do dia 07/05/2018, foram registrados diversas inundações e alagamentos em diversos canais entre eles estão os canais da Quintino Bocaiuva, 14 de março e Dr. Moraes (Bacia Estrada Nova); O 


\section{Risco hidroclimático e impacto das precipitações em planícies urbanas de Belém-Pa}

canal da Marquês de Herval, atrás da Unama da Alcindo Cacela (Bacia do Una); Os canais da Gentil com Guerra Passos, Canal da Cipriano Santos, Canal José Leal Martins (Bacia Tucunduba)

Os alagamentos não ocorreram apenas nas ruas dos bairros mais periféricos, aconteceram também nas principais avenidas da cidade como nas Avenidas Padre Eutíquio com Alcindo Cacela (Cremação), na travessa 25 de setembro, ao lado do Bosque Rodrigues Alves (Figura 13) e na Avenida João Paulo II (Marco)

Figura 13: Alagamentos registrados (A) Tv. Padre Eutíquio; (B) Tv. 25 de setembro, ao lado do Bosque Rodrigues Alves.
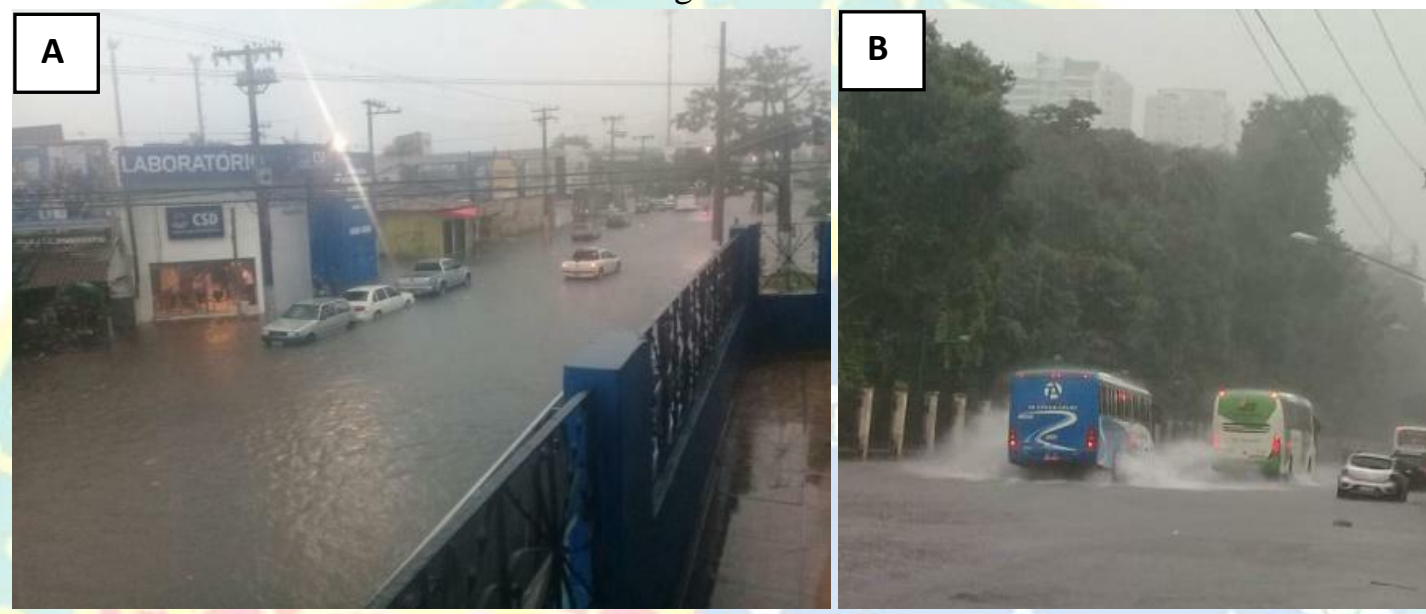

Fonte: Jessica Alves, 2018

Quando a água precipita em volume acima do esperado, principalmente em ambiente densamente ocupado no perímetro urbano, uma das consequências são os grandes riscos de doenças, que à população principalmente de famílias assentadas precariamente estão sujeitas, perdas de bens materiais e desvalorização dos imóveis (Figura 14). 
Figura 14: Alguns riscos que as inundações oferecem à população atingida. (A) Contato com água contaminada risco à saúde; (B) Dificuldade de sair de casa; (C) Perdas Materiais (D) Desvalorização imobiliária.

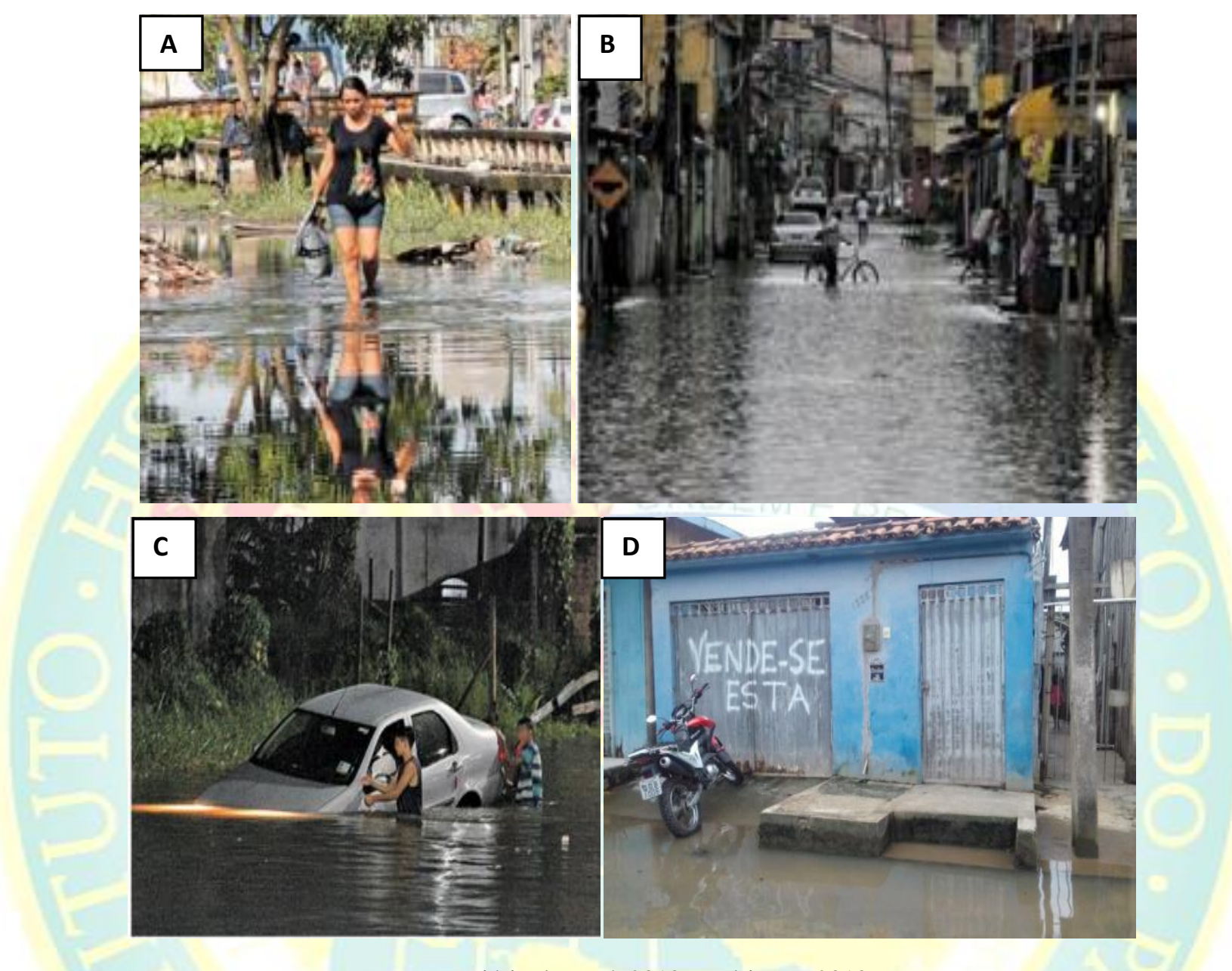

Fonte: Diário do Pará, 2018; Rodrigues, 2018

Essas áreas passíveis de serem atingidas por processos de enchentes e inundações, geralmente são muito populosas e as pessoas que habitam essas áreas estão sujeitas a danos à integridade física e a saúde, perdas materiais e patrimoniais. Normalmente, essas áreas correspondem a núcleos habitacionais de baixa renda.

\section{CONSIDERAÇÕES FINAIS}

Os aspectos que condicionam a ocorrência de inundações e alagamentos estão diretamente relacionados a fatores naturais como relevo, tamanho e forma da bacia, gradiente hidráulico do rio, dinâmica de escoamento pluvial, falta de arborização e alto índice pluviométrico.

Já os fatores antrópicos estão relacionados à impermeabilização dos terrenos; obras e intervenções estruturais diversas ao longo dos cursos d'água; erosão e assoreamento. Por isso, o acompanhamento de fatores climáticos como índice pluviométrico para as áreas de bacias urbanas, é de fundamental importância no controle de enchentes em bacias urbanas. 


\section{Risco hidroclimático e impacto das precipitações em planícies urbanas de Belém-Pa}

As inundações de extensas áreas de baixada estão associadas principalmente à planície de inundação dos rios e canais, onde a dinâmica do escoamento superficial é lenta, é grande o número de moradias afetadas geralmente não há registro de perda de vidas humanas, entretanto problemas como surtos de leptospirose, diarreia entre outras doenças associadas à água, são bastante frequentes, assim como perdas de bens materiais.

\section{BIBLIOGRAFIA}

ADLER, F. R. e TANNER, C. J. Ecossistemas urbanos: princípios ecológicos para o ambiente construído. São Paulo, Oficina de texto, 2015.

AMORIM, M. C. da C. T. SANT'ANA NETO, J. L. (Orgs). Climatologia urbana e regional. São Paulo: Outras expressões, 2013.

ANGELOCCI, L. R. e SENTELHAS, P. C. Variabilidade, Anomalia e Mudança Climática. Material didático da disciplina LCE306 -Meteorologia Agrícola - Turmas 1, 4,5 e 6 Departamento de Ciências Exatas- setor de Agrometeorologia - ESAL/USP - 2007

AYOADE, J. O. Introdução à climatologia para os trópicos. $9^{\circ}$ ed. Rio de Janeiro: Bertrand Brasil, 2003.

CONFALONIERI, U. E. C. Variabilidade climática, vulnerabilidade social e saúde no Brasil. Terra Livre São Paulo Ano 19 - vol. I - n. 20 p. 193-204 jan/jul. 2003

MARENGO, J. A. e NOBREGA, C. A. Clima da região amazônica. IN: CAVALCANTI, I. F. de B.; FERREIRA, N. J.; DA SILVA, M. G. A. J.; DIAS. M. A. F. da S. (Orgs.). Tempo e Clima no Brasil. São Paulo: Oficina de Texto, 2009.

NIMER, E. Clima. IN: IBGE, Geografia do Brasil: região norte. Rio de Janeiro, SERGRAF- IBGE, 1977.

RODRIGUES, J. E. C. O Clima e o Tempo na Amazônia. Belém PA., Editora Estudos Amazônicos, 2012.

RODRIGUES, J. E. C.; LUZ, L. M.; MARINHO, A, V. do R. A variabilidade climática da precipitação em bacias urbanas da cidade de Belém-PA. IN: SILVA, C. N.; LUZ, L. M.; PONTE, F. C.; RODRIGUES, J. E. C. Belém dos 400 anos: análises geográficas e impactos antropogênicos na cidade. Belém-PA: GAPTA/UFPA, 2017.

https://twitter.com/belemnoticiass. Acessado em 08/05/2018

https://www.diarioonline.com.br/ acessado em 08/05/2018

http://www.inmet.gov.br/portal/ acessado em 08/05/2018

https://leismunicipais.com.br/a/pa/b/belem/lei-ordinaria/2010/873/8739/lei-ordinaria-n-8739-2010-institui-oprograma-municipal-de-regularizacao-fundiaria-programa-chao-legal-e-da-outras providencias

Texto recebido em: $31 / 01 / 2020$

Texto aprovado em: 30/05/2021 